Berkala Ilmu Perpustakaan dan Informasi, Vol. 14, No. 1, Juni 2018, Hal. 108-123 DOI: 10.22146/bip.31996

ISSN 1693-7740 (Print), ISSN 2477-0361 (Online)

Tersedia online di https://jurnal.ugm.ac.id/bip

\title{
Pengaruh soft dan hard services terhadap akreditasi dan loyalitas pemustaka
}

\author{
Sungadi ${ }^{1}$ \\ ${ }^{1}$ Perpustakaan Universitas Islam Indonesia \\ Email: sungadi@uii.ac.id
}

Naskah diterima: 4 Januari 2018, direvisi: 3 Maret 2018, disetujui: 24 April 2018

\begin{abstract}
ABSTRAK
Pendahuluan. Per Januari 2018 Direktorat Perpustakaan UII kembali mendapatkan akreditasi A dari Perpusnas RI, dan unit terbaik se-UII tahun 2017, perlu dikaji lebih lanjut.

Metode Penelitian. Pengambilan data dilakukan di Perpustakaan UII pada Juli-Oktober 2017, dengan sampel 252 mahasiswa diambil secara purposive sampling. Alat ukur yang digunakan adalah angket. Hipotesa dalam kajian ini adalah bahwa terdapat pengaruh antara jasa layanan soft dan hard terhadap loyalitas pemustaka melalui variabel intervening akreditasi.

Analisis data. Analisa dilakukan dengan regresi ganda dan path analysis dengan menggunakan program SPSS 16.0. Regresi ganda digunakan untuk menguji pengaruh langsung antar variabel, path analysis untuk mengetahui pengaruh variabel eksogen terhadap variabel endogen melalui variabel intervening.

Hasil dan pembahasan. Hasil analisa menunjukan tingkat mutu layanan dan loyalitas pada posisi tinggi-sangat tinggi $(79,75-82,83 \%)$. Pengaruh simultan layanan soft $\left(\mathrm{X}_{1}\right)$ dan layanan hard $\left(\mathrm{X}_{2}\right)$ terhadap loyalitas $(\mathrm{Z})$ melalui akreditasi (Y) naik dari 0,329 menjadi 0,442 (0,442>0,329). Artinya, secara simultan layanan soft $\left(\mathrm{X}_{1}\right)$, layanan hard $\left(\mathrm{X}_{2}\right)$ via akreditasi $(\mathrm{Y})$ berpengaruh terhadap loyalitas pemustaka $(\mathrm{Z})$.

Kesimpulan dan Saran. Dalam penelitian ini dapat diambil kesimpulan bahwa: Kualitas layanan di Direktorat Perpustakaan UII dalam kondisi tinggi s.d sangat tinggi, sementara tingkat kualitas penjaminan mutu (akreditasi) berkategori tinggi, dan loyalitas pemustaka pada tataran sangat tinggi. Hasil analisis data menunjukkan bahwa variabel kualitas jasa soft dan hard ada pengaruh secara langsung terhadap loyalitas pemustaka. Sementara itu variabel layanan soft dan hard melalui variabel akreditasi berpengaruh terhadap loyalitas pemustaka. Peneliti mendatang dapat mengembangkan penelitian ini dengan melibatkan seluruh perpustakaan di lingkungan UII sebagai objek kajian.
\end{abstract}

Kata Kunci: Akreditasi; Perpustakaan; Loyalitas; Pemustaka; Soft dan Hard services

\section{ABSTRACT}

Introduction. As of January 2018 The Directorate of UII Library re-obtained the accreditation A from the National Library of Indonesia, and also become the best unit of UII in 2017, it needs to have further evaluation.

Data collection method. The survey was conducted at UII Library in July-October 2017, with sample of 252 students as respondents using purposive sampling. The hypothesis in this paper was there is influence between soft and hard services to user loyalty through acceptable accreditation intervening variables.

Data analysis. The data was analysed by using multiple regression and path analysis in SPSS 16.0. Multiple regression was used to test direct influence between variables, while path analysis was used to determine the effect of exogenous variables on endogenous variables through intervening variable.

Results and Discussions. The results showed that the level of service quality and loyalty was high-very high (79.75-82.83\%). The simultaneous influence of soft service $\left(X_{1}\right)$ and hard service $\left(X_{2}\right)$ on loyalty $(Z)$ through accreditation $(Y)$ increased from 0.329 to $0.442(0.442>0.329)$. Simultaneously soft service $(X)$, hard service $\left(X_{2}\right)$ via accreditation $(Y)$-affected loyalty of library users $(Z)$. 
Conclusions. In this research can be concluded that: Quality of service in UII Library Directorate in high condition s.d very high, while quality assurance level (accreditation) categorized high, and loyality pemustaka at very high level. The result of data analysis shows that the variable of soft service quality and hard there is direct influence to loyalty pemustaka. Meanwhile, the variable of soft and hard service through accreditation variable has an effect on the loyalty of the user.

Future researchers can develop this research by involving all libraries within the UII as an object of study.

Keywords: Accreditation; Library; Loyalty; Reader; Soft and Hard Service

\section{A. PENDAhULUAN Latar Belakang}

Pengukuran perilaku kepuasan dan loyalitas seperti niat untuk memanfaatkan kembali atau merekomendasikan kepada orang lain memiliki sejarah panjang dalam pemasaran dan manajemen perpustakaan. Pengunjung yang puas dapat dilihat oleh manajemen perpustakaan sebagai hasil kinerja yang terukur. Namun yang lebih penting, kepuasan dipandang sebagai referensi terhadap loyalitas karena pengunjung yang tidak puas kecil kemungkinan akan berkunjung kembali dan menceritakan kepada teman atau koleganya. Perilaku loyalitas sangat penting bagi kelangsungan hidup jasa layanan perpustakaan di masa depan. Penelitian terdahulu berkonsentrasi pada teorema filosofis bagaimana kepuasan pengunjung dirumuskan dan konstruk mana yang bisa digunakan untuk memprediksi kepuasan dan loyalitas. Misalnya, hal ini dapat dikonfirmasi pada kajian bertema pengaruh persaingan terhadap kepuasan dan loyalitas pengunjung (Ross H. Taplin: 2013); (Dahan dkk: 2016); (Ahmad and Abawajy: 2014).

Persaingan global antar institusi akademis telah memaksa perpustakaan universitas untuk mengubah konsep konvensional layanan mereka dan peran tradisional menjadi penyedia layanan serba canggih yang bisa mengantarkannya pelayanan terbaik bagi pengguna mereka. Perpustakaan dengan keragaman koleksi yang dimiliki wajib memenuhi perluasan sumber informasi, seiring tingginya permintaan pengguna, aplikasi teknologi informasi, pendaftaran anggota yang tinggi, dan persaingan global antar sektor jasa yang semakin ketat. Dengan demikian sangat diperlukan adanya kemampuan perpustakaan untuk melakukan langkah-langkah konkrit dan tindakan nyata dalam rangka memenuhi harapan pengguna, sehingga akan menghasilkan kepuasan pengguna terhadap jasa layanannya.

Direktorat Perpustakaan Universitas Islam Indonesia Yogyakarta, saat ini telah Terakreditasi A oleh Perpustakaan Nasional Republik Indonesia Nomor 29/1/ee/XII.2014 tertanggal 24 Desember 2014 dan telah dilakukan akreditasi ulang dengan hasil nilai predikat Akreditasi A sesuai Sertifikat Akreditasi dari Perpusnas RI Nomor 0004/LAP.PT/I/2018 tertanggal 10 Januari 2018. Dengan predikat ini Direktorat Perpustakaan UII senantiasa berusaha untuk melakukan pelayanan terbaik bagi para pemustakanya. Selain akreditasi secara nasional tersebut, untuk tingkat internal UII, Direktorat Perpustakaan UII juga dinobatkan sebagai pengelola Penjaminan Mutu Terbaik pada tataran Badan dan Direktorat di lingkungan UII pada tahun 2017. Predikat akreditasi A tersebut menunjukkan kualitas jasa, yang mendorong ghirah dalam memberikan servis terhadap pemustaka, sehingga pelanggan merasa nyaman dan puas dengan apa yang diperolehnya.

Direktorat Perpustakaan merupakan salah satu pilar penting di UII yang merupakan salah satu perguruan tinggi terkemuka di Yogyakarta. Pada 3 (tiga) tahun terakhir jumlah mahasiswa/mahasiswi baru Universitas Islam Indonesia (UII) mengalami penurunan (HIMAH Online, 2016). Mahasiswa yang melakukan daftar ulang tahun ajaran 2016/2017 menurun apabila dibandingkan dengan tahun sebelumnya. Sebanyak 4.201 mahasiswa baru yang melakukan daftar ulang pada tahun 2016/2017, dibanding tahun ajaran 2015/2016 sebesar 5.386 mahasiswa (turun 22\%) serta tahun ajaran 2014/2015 sebesar 6.649 
mahasiswa (turun 19\%). Akan tetapi secara keseluruhan jumlah pendaftar hanya sedikit mengalami penurunan dimana tahun ini terdapat 27.297 pendaftar dan tahun sebelumnya 27.654 pendaftar (turun 1,29\%). Kondisi ini akan berakibat buruk untuk kedepannya bagi UII, jika kondisi ini tetap dibiarkan maka Direktorat Perpustakaan UII sebagai penunjang Catur Dharma UII perlu ikut bertanggung jawab dengan melakukan kinerja terbaiknya.

Atas dasar uraian di atas maka dirasa perlu untuk melakukan penelitian tentang analisis pengaruh akreditasi perpustakaan terhadap loyalitas pemustaka (studi kasus pada Direktorat Perpustakaan UII) yang meliputi kualitas jasa pelayanan yang soft dan hard dalam upaya meningkatkan kepercayaan mahasiswa UII.

\section{Rumusan Masalah}

Dari latar belakang di atas, maka dapat dikemukakan rumusan masalah antara lain: pertama bagaimana tingkat kualitas jasa soft, jasa hard, jaminan mutu (akreditasi), dan loyalitas pemustaka?; kedua secara parsial adakah pengaruh langsung antar masing-masing variabel?; ketiga apakah variabel independen (eksogen) secara bersama-sama atau secara individual berpengaruh terhadap variabel dependen(endogen)?

\section{Tujuan Penelitian}

Sesuai dengan rumusan masalah di atas, maka hasil yang ingin diperoleh dari penelitian ini adalah: pertama untuk menganalisis dan mengetahui tingkat kualitas jasa soft, jasa hard, jaminan mutu (akreditasi), dan loyalitas pemustaka Direktorat Perpustakaan UII. Kedua untuk menganalisis dan mengetahui pengaruh langsung antar variabel, yaitu antara variabel layanan soft $\left(\mathrm{X}_{1}\right)$ dan variabel layanan hard $\left(\mathrm{X}_{2}\right)$ masing-masing pengaruhnya terhadap akreditasi (Y); variabel layanan soft $\left(\mathrm{X}_{1}\right)$ dan variabel layanan hard $\left(\mathrm{X}_{2}\right)$ masing-masing pengaruhnya terhadap terhadap loyalitas pemustaka $(Z)$, serta pengaruh antara variabel akreditasi (Y) terhadap variabel loyalitas (Z), sebagaimana disajikan pada Gambar 1. Ketiga untuk menganalisis dan mengetahui Pengaruh tidak lansung antara variabel layanan soft $\left(\mathrm{X}_{1}\right)$ dan layanan hard $\left(\mathrm{X}_{2}\right)$ melaui akreditasi $(\mathrm{Y})$ terhadap loyalitas pemustaka (Z) baik secara bersama-sama maupun individual, sebagaimana disajikan pada Gambar 1.

\section{Manfaat Penelitian}

Manfaat studi ini adalah untuk menambah pengetahuan dalam bidang ilmu pengetahuan khususnya dalam bidang pemasaran mengenai kualitas jasa. Sedangkan bagi pihak Direktorat Perpustakaan UII, penelitian ini akan membantu dalam mengetahui bahwa kualitas jasa soft dan hard yang baik akan berpengaruh baik pula terhadap kepercayaan dan loyalitas pemustaka, sehingga akan membantu Direktorat Perpustakaan UII untuk selalu mengembangkan kualitas jasa mereka.

Pentingnya dari penelitian ini adalah pada ide kreatif yang berkaitan kualitas layanan dengan adanya peningkatan layanan terhadap ketersediaan materi perpustakaan dalam bentuk digital yang disajikan secara online maupun offline demi terciptanya jaminan mutu bagi perpustakaan di masa mendatang.

\section{Hipotesis}

Dari rumusan masalah penelitian, maka dapat dirumuskan hipotesis sebagai berikut:

1. Kualitas jasa soft $\left(\mathrm{X}_{1}\right)$ berpengaruh positif terhadap loyalitas pemustaka (Z).

2. Kualitas jasa hard $\left(\mathrm{X}_{2}\right)$ berpengaruh positif terhadap loyalitas pemustaka $(Z)$.

3. Kualitas jasa soft $\left(\mathrm{X}_{1}\right)$ berpengaruh positif terhadap akreditasi perpustakaan (Y).

4. Kualitas jasa hard $\left(\mathrm{X}_{2}\right)$ berpengaruh positif terhadap akreditasi perpustakaan (Y).

5. Kualitas akreditasi perpustakaan (Y) berpengaruh positif terhadap loyalitas pemustaka (Z).

6. Kualitas jasa soft $\left(\mathrm{X}_{1}\right)$, jasa hard $\left(\mathrm{X}_{2}\right)$, melalui akreditasi perpustakaan $(\mathrm{Y})$ secara bersama-sama maupun individual berpengaruh positif terhadap loyalitas pemustaka $(Z)$.

\section{Paradigma Penelitian}

Berdasarkan pada hipotesis tersebut, maka dapat dibuat kerangka penelitian seperti pada Gambar 1. 


\section{B. TINJAUAN PUSTAKA}

Kajian loyalitas pemustaka sampai saat ini masih memiliki daya tarik untuk diteliti, karena menyangkut kinerja perpustakaan seiring dengan kehadiran teknologi informasi yang berkembang semakin cepat menjadikan perpustakaan perlu mengimbanginya. Perpustakaan di negara berkembang telah mencatat tingkat pertumbuhan yang tinggi dalam dekade tahun-tahun belakangan ini. Dari waktu ke waktu kebutuhan informasi sangat dibutuhkan oleh para ilmuwan baik secara kualitas maupun kuantitas, sehingga perpustakaan dituntut untuk dapat meningkatkan kinerjanya, mulai dari keragaman koleksi, jaminan mutu pelayanan, dan berbagai fasilitas pendukung lainnya dalam rangka untuk memberikan kepuasan terhadap pengguna. Keragaman koleksi ini antara lain meliputi: buku dalam bentuk cetak dan e-book, jurnal tercetak maupun e-journal, local content dalam bentuk cetak dan digital. Online access seperti: Scopus, ScienceDirect, Ebsco, ProQuest, Westlaw, e-books, Jstore, SciFinder, iGPublising, dan Springer. Sementara itu jaminan mutu layanan ini terdiri dari: peminjaman dan pengembalian secara mandiri, buka layanan minimal 52 jam per minggu, kebebasan pengunjung perpustakaan membawa masuk tas ke ruang koleksi perpustakaan, dan lain-lain. Sedangkan sarana prasarana yang mesti ada, misalnya: letak perpustakaan yang mudah diakses, ruangan perpustakaan yang nyaman (ber AC), akses internet secara gratis, hotspot (wifi) dengan kecepatan akses tinggi, dan lain-lain. Keragaman koleksi, jaminan mutu layanan, dan sarana prasarana perpustakaan ini sering digunakan secara bergantian untuk mengukur tingkat loyalitas pengguna, sebab ketiga konsep tersebut saling berkaitan antara satu dengan yang lainnya. Pedramnia, Modiramani dan Ghanbarabadi (2012) melaporkan bahwa Ranganathan, seorang filsuf terkenal di bidang Ilmu Perpustakaan dan Informasi (Library and Information Science/LIS), selalu memandang pengguna sebagai inti semua aktivitas perpustakaan dan menekankan bahwa pustakawan harus melayani informasi dengan benar terhadap pengguna pada waktu yang tepat. Jelas, kepuasan pengguna perpustakaan (yaitu mahasiswa) bergantung pada kualitas layanan yang merupakan ukuran signifikan kualitas layanan yang mampu diberikan oleh perpustakaan.

Domain inti dari kualitas layanan adalah: jaminan mutu, pengendalian proses, area yang harus dilindungi, prosedur, dan penggunaan hasil (Blackmur, 2004; Brennan and Shah, 2000; Perellon, 2005). Lima domain ini dapat digunakan untuk membandingkan sistem penjaminan mutu di berbagai perpustakaan. Perellon (2005) berpendapat bahwa jaminan mutu dapat digunakan untuk tujuan sumatif atau formatif. Tujuan sumatif menekankan hubungan antara hasil dengan beberapa tujuan tertentu (misalnya Pendanaan) sementara objek formatif berfokus pada peningkatan kualitas institusi. Proses penjaminan mutu bisa dikendalikan oleh dua otoritas yaitu antara pemerintah dan institusi pendidikan tinggi (Perellon, 2007). Area yang harus dilindungi mencakup semua aspek kualitas jaminan mutu yang meliputi kombinasi dari semua kegiatan antara lain perpustakaan sebagai penunjang tri dharma perguruan tinggi, pengajaran, penelitian, dan manajemen kelembagaan. Prosedurnya meliputi pertanyaan yang berkaitan dengan isu metodologis dan tingkat keterlibatan institusi pendidikan tinggi. Data yang dikumpulkan melalui penjaminan mutu dapat digunakan untuk umum pada umumnya atau hanya untuk institusi pendidikan tinggi, dan untuk tujuan kebijakan lainnya seperti pendanaan.

Namun, perbedaan perspektif pada lima domain saling terkait. Persoalan utama adalah hubungan kekuatan antara pemerintah dan institusi pendidikan tinggi (Brennan dan Shah, 2000). Pemerintah lebih memilih untuk menggunakan kualitas jaminan mutu sebagai pendorong yang kuat untuk mereformasi pendidikan tinggi sementara universitas lebih memilih untuk mempertahankan prestise mereka tanpa pengaruh kuat pemerintah. Konflik potensial antara universitas dan pemerintah mengarah pada berbagai jenis sistem penjaminan mutu pada sistem pendidikan tinggi (Orsingher, 2006). Sebagai 
contoh, pemerintah cenderung memilih untuk memberikan hasil audit kepada masyarakat umum dan juga institusi pendidikan tinggi, dan juga pemerintah lebih memilih untuk menghubungkan hasil penjaminan mutu dengan berbagai inisiatif kebijakan pemerintah lainnya. Namun, hubungan antara penjaminan mutu dan inisiatif kebijakan pemerintah lainnya berbeda menurut tata kelola masing-masing daerah (Salter and Tapper, 2000). Institusi pendidikan tinggi cenderung menerapkan evaluasi formatif yang memungkinkan ada otonomi terhadap institusinya dan dengan demikian pendidikan tinggi cenderung lebih menekankan pada peningkatan kualitas, sementara pemerintah cenderung menerapkan evaluasi sumatif dan menekankan akuntabilitas (Brennan and Shah, 2000).

Sementara itu, jika dilihat dari sisi kajian terkait dengan kualitas layanan, kepuasan pelanggan, dan loyalitas pemakai telah dikaji oleh peneliti terdahulu antara lain: Dahan dkk (2016) melakukan kajian terkait dengan persepsi pengguna terhadap kualitas pelayanan perpustakaan akademik, riset ini merupakan studi kasus di Perpustakaan Universitas Pahang Malaysia (UMP). Ahmad dan Abawajy (2014) meneliti tentang model penilaian kualitas pelayanan perpustakaan digital. Taplin (2013) mengkaji tentang pengaruh persaingan terhadap kepuasan dan loyalitas pengunjung. Sementara itu Kasiri dkk. (2017) meriset bertema integrasi standardisasi dan kustomisasi: yang berdampak terhadap kualitas layanan, kepuasan pelanggan, dan loyalitas. Meesala dan Paul (2018) menyelidiki tentang kualitas layanan, kepuasan konsumen dan loyalitas di rumah sakit: berpikir untuk masa depan. Lierop dan Geneidy (2016) mengkaji tentang Menikmati loyalitas: Hubungan antara kualitas layanan, kepuasan pelanggan, dan niat perilaku dalam jasa layanan umum. Jung Cheol Shin (2017) mengkritisi tentang sistem penjaminan mutu sebagai alat kebijakan pendidikan tinggi di Korea: konvergensi internasional dan konteks lokal. Yu-Hern Chang dan Chung-Hsing Yeh (2017) meneliti tentang Tanggung jawab sosial perusahaan dan loyalitas pelanggan dalam layanan bus antarkota. Wolter dkk. (2017) mengkaji tentang Menciptakan Kesetiaan Pelanggan Ultimate Melalui Keyakinan Loyalitas dan Identifikasi PerusahaanPelanggan.

Beberapa referensi tersebut di atas dipakai sebagai bahan analisis dan pembahasan terkait dengan tema penelitian ini. Keterkaitan kualitas layanan dan jaminan mutu, serta loyalitas pemakai semuanya bertujuan untuk tersedianyan layanan berkualitas di masa yang akan datang.

\section{METODE PENELITIAN}

Penelitian dilakukan di Universitas Islam Indonesia Yogyakarta. Pemilihan lokasi penelitian ini dengan mempertimbangkan beberapa aspek antara lain: masalah yang diteliti berada di Universitas Islam Indonesia. Penelitian dilakukan antara bulan Juli - Oktober 2017.

Populasi penelitian adalah mahasiswa UII yang secara kebetulan berkunjung di Direktorat Perpustakaan UII sebagai responden penelitian. Pengambilan sampel dengan purposive sampling untuk dijadikan responden penelitian, yang berarti teknik pengambilan sampel secara sengaja oleh peneliti. Sugiyono (2011) menjelaskan bahwa Sampling Purposive adalah teknik penentuan sampel dengan pertimbangan tertentu. Pertimbangan tertentu ini adalah, bahwa jumlah total mahasiswa aktif UII saat ini lebih dari 23.000 (duapuluhtiga ribu) orang (http://pmb.uii.ac.id/tentang-universitas-islamindonesia-2/ diakses pada tanggal 21-02-2018) yang tersebar di beberapa lokasi kampus UII. Sementara pengunjung perpustakaan pusat ratarata per hari sebanyak 819 orang (Data Direktorat Perputakaan UII: 2016). Dari jumlah total data mahasiswa aktif UII dan rata-rata pengunjung perpustakaan pusat per hari tersebut hanya diambil terhadap mahasiswa yang secara kebetulan berkunjung ke Perpustakaan Pusat UII pada saat dilakukan penelitian. Jadi, pengambilan sampel dalam riset ini adalah dengan cara melibatkan mahasiswa UII yang kebetulan sedang berkunjung ke perpustakaan sehingga mereka mengetahui dan merasakan secara langsung tentang apa yang mereka alami terhadap kualitas layanan perpustakaan. 
Penentuan sampel dilakukan dengan mempertimbangkan, bahwa data pengunjung perpustakaan pada tahun 2016 di Direktorat Perpustakaan UII berjumlah 819 orang per hari. Angka populasi 819 oleh Isaac dan Michael (Sugiyono: 2011) dibulatkan menjadi 850, sehingga pada tabel telah ditentukan sampel sebanyak 252 orang (mahasiswa). Jadi jumlah sampel pada penelitian ini adalah 252 orang.

Pengambilan data dilakukan dengan menyebarkan angket kepada responden, kemudian dari data yang terkumpul dilakukan olah data secara deskriptif yang meliputi tabulasi dan interpretasi data. Analisis data dilakukan dengan metode analisis deskriptif, regresi ganda, dan analisis jalur (path analysis) dengan menggunakan program SPSS versi 16.

Menurut Bohrnstedt (1974 dalam Riduwan, 2015) yang dimakud dengan analisis jalur (path analysis) diterjemahkan secara bebas, adalah teknik untuk mengetahui pengaruh antara variabel independen terhadap variabel dependen dari sekumpulan korelasi yang diamati, dengan serangkaian himpunan hubungan asimetris kausal antara variabel. Jadi model path analysis dipakai untuk menganalisis pola hubungan antar variabel dengan tujuan untuk membuktikan pengaruh langsung ataupun tidak langsung dari serangkaian variabel independen (eksogen) terhadap variabel dependen (endogen). Penelitian ini melibatkan variabel intervening sebagai variabel perantara, sehingga dalam menganalisis data menggunakan analisis jalur.

\section{HASIL DAN PEMBAHASAN Demografi Responden}

Data responden berdasarkan tahun angkatan dan fakultas asalam mahasiswa dapat dilihat pada Tabel.1 dan Tabel.2.

Hasil studi dari demografi responden berdasarkan gender menunjukkan bahwa mahasiswa UII yang berjenis kelamin laki-laki sebesar 96 orang $(38.10 \%)$ dan perempuan sebesar 156 orang $(61.90 \%)$, dari total sampel 252 responden.

Pada Tabel 1 tampak, bahwa responden maha-siswa berasal dari berbagai angkatan antara lain: tahun 2017 sebanyak 139 orang
(55.16\%), angkatan tahun 2013 sebesar 34 orang (13.49\%), angkatan tahun 2014 sebesar 27 orang (10.71\%) angkatan tahun 2016 sebanyak 25 orang (9.92\%), angkatan tahun 2015 sebanyak 23 orang $(9.13 \%)$, angkatan 2012 sebanyak 5 orang (1.98\%), dan angkatan tahun 2011 sebanyak $4(1.59 \%)$.

Sementara itu pada Tabel 2 tampak bahwa jumlah mahasiswa UII yang berkunjung ke Direktorat Perpustakaan UII paling banyak mahasiswa berasal dari Fakultas Ilmu Agama Islam (FIAI) sebanyak 86 orang (34.13\%), disusul berturut-turut Fakultas Psikologi dan Ilmu Sosial Budaya (FPSB) sebanyak 77 orang (30.56\%), Fakultas Teknologi Industri (FTI) sebanyak 38 orang (15.08\%), Fakultas MIPA (FMIPA) sebanyak 34 orang (13.49\%), Fakultas Ekonomi (FE) dan Fakultas Teknik Sipil dan Perencanaan (FTSP) masing-masing sebanyak 8 orang $(3.17 \%)$, dan Fakultas Kedokteran (FK) sebanyak 1 orang $(0.40 \%)$.

\section{Uji Reliabilitas dan Validitas}

Pada Tabel 3 tampak bahwa seluruh instrumen penelitian, maka dapat diketahui bahwa nilai $r_{\text {hitung }}$ lebih besar dari 0.6 dimana dalam ketentuan menyebutkan bahwa apabila harga $r_{\text {hitung }}>0.6$, sehingga kuisioner dalam riset ini dimaknai andal/teruji. Kesimpulannya nilai item-item pertanyaan semua kuisioner dapat dinyatakan andal dan teruji sebagai instrumen riset. Sementara tingkat kesahihan dari semua instrumen penelitian dari hasil hitungan dapat diketahui bahwa $r_{\text {hitung }}$ lebih besar dari $r_{\text {tabel }}$. Dimana nilai $\mathrm{r}_{\text {tabel }}$ untuk $\mathrm{N}=252$ dengan tingkat kesalahan 5\% adalah 0.138 dan 0.181 untuk tingkat kesalahan 1\%. Kesimpulannya adalah semua item pertanyaan pada variabel ini dinyatakan valid.

\section{Persepsi Responden terhadap Kualitas Layanan}

Merujuk pada Tabel 4 dapat dijelaskan, bahwa persepsi mahasiswa terhadap Layanan Soft Direktorat Perpustakaan UII berada pada kategori tinggi dengan angka persepsi sebesar $79,75 \%$. Sementara persepsi mahasiswa terhadap Layanan hard Direktorat Perpustakaan UII terletak pada tingkat sangat 
tinggi dengan nilai persepsi sebesar $82,83 \%$. Sedangkan tingkat Kualitas Jaminan Mutu (Akreditasi) Direktorat Perpustakaan UII terletak pada tingkat tinggi dengan skor nilai persepsi sebesar $80 \%$. Lebih lanjut tingkat Loyalitas Pemustaka Direktorat Perpustakaan UII terletak pada tingkat sangat tinggi, dengan besaran persepsi bernilai $80,043 \%$.

\section{Analisis Jalur (Path Analysis) \\ Koefisien Jalur Model I}

Merujuk hasil perhitungan pada Tabel 6 Type Regression I pada tabel Coefficients terbukti bahwa angka signifikansi dari ke-2 faktor yakni $X_{1}=0,000$ dan $X_{2}=0,000<0,05$. Hitungan tersebut membuktikan bahwa Type Regression I, yaitu variabel jasa layanan soft $\left(\mathrm{X}_{1}\right)$ dan jasa layanan hard $\left(\mathrm{X}_{2}\right)$ berpengaruh signifikan terhadap akreditasi (Y). Jumlah nilai $\mathrm{R}^{2}$ yang tercantum pada Tabel 5 adalah senilai .570, masalah itu membuktikan bahwa nilai pengaruh $\mathrm{X}_{1}$ dan $\mathrm{X}_{2}$ terhadap $\mathrm{Y}$ adalah sebesar 57,0\% sementara sisa nilai angka 43\% menunjukkan andil dari faktor-faktor lain yang tidak terdapat dalam studi ini. Dengan demikian dapat diketahui diagram jalur model struktur I seperti pada Gambar 2.

\section{Koefisien Jalur Model II}

Merujuk pada Tabel 5 Type Regression II Coefficients terbukti bahwa angka signifikansi dari ke-2 variabel yaitu $X_{1}=0,000$ dan $X_{2}=$ $0,000<0,05 ; \mathrm{Y}=0,066>0,05$. Hitungan tersebut membuktikan bahwa Type Regression II, yaitu variabel jasa layanan soft $\left(\mathrm{X}_{1}\right)$ dan jasa layanan hard $\left(\mathrm{X}_{2}\right)$ berpengaruh signifikan terhadap loyalitas pemustaka (Z). Sementara hitungan akreditasi perpustakaan (Y) tidak berpengaruh pada loyalitas pemustaka. Jumlah nilai $\mathrm{R}^{2}$ yang tercantum pada Tabel 4 adalah senilai .344, masalah itu membuktikan bahwa nilai keuatan $\mathrm{X}_{1}, \mathrm{X}_{2}$ dan $\mathrm{Y}$ kepada $\mathrm{Z}$ adalah setara $34,4 \%$ sementara sisa nilai angka $65,6 \%$ menunjukkan andil dari faktor-faktor di luar studi ini.

Dengan demikian dapat diketahui diagram jalur model struktur II sebagai berikut (Gambar 3):
1. Analisis pengaruh $\mathrm{X}_{1}$ terhadap $\mathrm{Y}$ : dari analisis di atas didapat angka signifikansi $\mathrm{X}_{1}$ senilai 0,000 lebih kecil dari 0,05. Hal ini bisa dinyatakan bahwa secara langsung ada kekuatan yang substansial untuk jasa layanan soft $\left(\mathrm{X}_{1}\right)$ terhadap akreditasi $(\mathrm{Y})$.

2. Analisis pengaruh $\mathrm{X}_{2}$ terhadap $\mathrm{Y}$ : dari analisis di atas didapat angka signifikansi $\mathrm{X}_{2}$ senilai 0,000 kurang dari 0,05 . Hal ini bisa dinyatakan bahwa secara langsung ada kekuatan yang substansial untuk jasa layanan hard $\left(\mathrm{X}_{2}\right)$ terhadap akreditasi $(\mathrm{Y})$.

3. Analisis Pengaruh $X_{1}$ terhadap Z: dari analisis didapat angka signifikansi $X_{1}$ senilai 0,000 kurang dari 0,05 . Hal ini bisa dinyatakan bahwa secara langsung ada kekuatan yang substansial untuk jasa layanan soft $\left(\mathrm{X}_{1}\right)$ terhadap loyalitas pemustaka $(Z)$.

4. Analisis pengaruh $X_{2}$ terhadap $Z$ : dari analisis didapat angka signifikansi $\mathrm{X}_{2}$ senilai 0,000 kurang dari 0,05 . Sehingga bisa dinyatakan bahwa secara langsung ada kekuatan yang substansial untuk jasa layanan hard (X2) terhadap loyalitas pemustaka (Z).

5. Analisis pengaruh $\mathrm{Y}$ terhadap $\mathrm{Z}$ : dari analisis didapat angka bahwa nilai signifikansi Y senilai 0,066 lebih besar 0,05. Maka bisa dinyatakan bahwa secara langsung tidak ada kekuatan antara akreditasi terhadap loyalitas pemustaka.

6. Secara individual variabel layanan soft perpustakaan $\left(\mathrm{X}_{1}\right)$ lewat jalur variabel akreditasi perpustakaan (Y) kepada variabel loyalitas pemustaka (Z): terbukti kekuatan langsung yang disumbang $X_{1}$ kepada $Z$ setara 0,239 . Sementara kekuatan tidak langsung $\mathrm{X}_{1}$ lewat jalur $\mathrm{Y}$ bagi $\mathrm{Z}$ merupakan hasil pengali antara angka beta $X_{1}$ kepada $Y$ dengan angka beta $\mathrm{Y}$ kepada $\mathrm{Z}\left(\mathrm{X}_{1} \mathrm{Y} \mathrm{Z}\right)$ yakni : $0,239 \times 0,233=0,056$. Sehingga kekuatan seluruhnya yang diperoleh $\mathrm{X}_{1}$ kepada $\mathrm{Z}$ adalah kekuatan langsung plus kekuatan tidak langsung yakni : 0,239+ $0,056=0,295$. Dengan demikian hasil perhitungan di atas membuktikan bahwa pengaruh jasa layanan soft terhadap 
loyalitas pemustaka melalui akreditasi mengalami kenaikan dari 0,239 menjadi 0,295 . Angka hasil hitungan tidak langsung sebesar 0,295 bermakna, bahwa angka kekuatan tidak langsung ini lebih lebih besar jika dibandingkan dengan angka kekuatan langsung $(0,295>0,239)$, maka hal ini membuktikan bahwa layanan soft $\left(\mathrm{X}_{1}\right)$ melalui akreditasi $(\mathrm{Y})$ berpengaruh terhadap loyalitas pemustaka $(Z)$.

7. Analisis individual pengaruh layanan hard $\left(\mathrm{X}_{2}\right)$ lewat akreditasi (Y) kepada loyalitas (Z): tampak adanya kekuatan langsung yang disumbangkan $X_{2}$ kepada $Z$ senilai 0,294. Sementara kekuatan tidak langsung $X_{2}$ lewat Y kepada Z (X2 Y Z) merupakan perlipatan antara angka beta $X_{2}$ kepada $Y$ dengan angka beta $X_{2}$ kepada $Z$ yakni : 0,601 x 0,294= 0,177 . Dengan demikian kekuatan global yang dihasilkan $\mathrm{X}_{2}$ bagi $\mathrm{Z}$ merupakan kekuatan langsung plus kekuatan tidak langsung yakni : $0,294+0,177=0,471$. Dengan demikian hasil perhitungan di atas membuktikan bahwa pengaruh jasa layanan hard terhadap loyalitas pemustaka melalui akreditasi mengalami kenaikan dari 0,294 menjadi 0,471. Angka hasil tidak langsung sebesar 0,471 memiliki makna, bahwa angka kekuatan tidak langsung lebih lebih besar jika dibandingkan dengan angka kekuatan langsung $(0,471>0294)$, maka hal ini membuktikan bahwa layanan hard $\left(\mathrm{X}_{2}\right)$ melalui akreditasi $(\mathrm{Y})$ berpengaruh terhadap loyalitas pemustaka $(Z)$.

8. Secara bersama-sama (gabungan) antara variabel layanan soft perpustakaan $\left(\mathrm{X}_{1}\right)$ dengan variabel layanan hard $\left(\mathrm{X}_{2}\right)$ melalui jalur variabel akreditasi perpustakaan (Y) kepada variabel loyalitas pemustaka $(Z)$ : terbukti kekuatan langsung yang disumbang $X_{1}$ dengan $X_{2}$ kepada $Z$ setara 0,329. Sementara kekuatan tidak langsung $X_{1}$ dengan $\mathrm{X}_{2}$ lewat jalur $\mathrm{Y}$ bagi $\mathrm{Z}$ merupakan hasil pengali antara angka beta $X_{1}$ dan $X_{2}$ kepada $\mathrm{Y}$ dengan angka beta $\mathrm{X}_{1}$ dan $\mathrm{X}_{2}$ kepada $\mathrm{Z}\left(\mathrm{X}_{1}\right.$ dan $\left.\mathrm{X}_{2} \mathrm{Y} \mathrm{Z}\right)$ yakni : 0,329 $\mathrm{x}$ $0,344=0,113$. Sehingga kekuatan seluruhnya yang diperoleh $\mathrm{X}_{1}$ dan $\mathrm{X}_{2}$ kepada $\mathrm{Z}$ adalah kekuatan langsung plus kekuatan tidak langsung yakni : 0,329 $+0,113=$ 0,442 . Dengan demikian hasil perhitungan di atas membuktikan, bahwa pengaruh gabungan antara jasa layanan soft dengan layanan hard terhadap loyalitas pemustaka melalui akreditasi mengalami kenaikan dari 0,329 menjadi 0,442. Angka hasil hitungan tidak langsung sebesar 0,442 ini bermakna, bahwa angka kekuatan tidak langsung ini lebih besar jika dibandingkan dengan angka kekuatan langsung $(0,442>0,329)$, maka hal ini membuktikan bahwa secara bersamasama antara layanan soft $\left(\mathrm{X}_{1}\right)$ dengan layanan hard $\left(\mathrm{X}_{2}\right)$ melalui akreditasi $(\mathrm{Y})$ berpengaruh terhadap loyalitas pemustaka (Z).

Dari hasil hitungan dan pembahasan di atas, maka dapat diambil kesimpulan bahwa hipotesis yang menyatakan:

1. Kualitas jasa soft $\left(\mathrm{X}_{1}\right)$ berpengaruh positif terhadap akreditasi perpustakaan (Y) diterima.

2. Kualitas jasa hard $\left(\mathrm{X}_{2}\right)$ berpengaruh positif terhadap akreditasi perpustakaan (Y) diterima.

3. Kualitas jasa soft $\left(\mathrm{X}_{1}\right)$ berpengaruh positif terhadap loyalitas pemustaka $(\mathrm{Z})$ diterima.

4. Kualitas jasa hard $\left(\mathrm{X}_{2}\right)$ berpengaruh positif terhadap loyalitas pemustaka $(\mathrm{Z})$ diterima.

5. Kualitas akreditasi perpustakaan (Y) berpengaruh positif terhadap loyalitas pemustaka $(Z)$ ditolak.

6. Kualitas jasa soft $\left(\mathrm{X}_{1}\right)$, jasa hard $\left(\mathrm{X}_{2}\right)$, melalui akreditasi perpustakaan (Y) secara bersama-sama maupun individual berpengaruh positif terhadap loyalitas pemustaka $(Z)$ diterima.

\section{Uji Normalitas Data}

Uji normalitas data dimaksudkan untuk membuktikan apakah angka-angka hasil riset dalam kondisi normal atau tidak. Mengingat pada statistik parametrik angka-angka riset yang berdistribusi normal merupakan suatu keharusan dan sebagai syarat mutlak yang mesti terpenuhi. Uji normalitas data pada riset ini memakai Uji Kolmogorov-Smirnov. Dari output data, terdapat angka siginifikansi senilai $0.070>0.05$, dimana hasil ini bisa dikatakan 
bahwa uji data pada studi ini berdistribusi normal.

Berdasarkan hasil analisis dan merujuk pada hasil hitung Tabel 5 (Type Regression I) di bagan Coefficients terbukti bahwa angka signifikasi dari dua faktor yakni $\mathrm{X}_{1}=0,000$ dan $\mathrm{X}_{2}=0,000>0,05$. Hitungan tersebut membuktikan bahwa Type Regression I, yaitu variabel jasa layanan soft $\left(\mathrm{X}_{1}\right)$ dan jasa layanan hard $\left(\mathrm{X}_{2}\right)$ berpengaruh signifikan terhadap akreditasi (Y). Jumlah nilai $\mathrm{R}^{2}$ Tabel 5 di atas terdapat hasil hitung senilai 0,570 , masalah itu membuktikan bahwa nilai pengaruh $\mathrm{X}_{1}$ dan $\mathrm{X}_{2}$ terhadap $\mathrm{Y}$ adalah sebesar 57,0\% sementara sisa nilai angka $43 \%$ menunjukkan andil dari faktorfaktor lain yang tidak terdapat pada studi ini. Artinya bahwa faktor yang mempengaruhi akreditasi bukan hanya faktor jasa soft dan hard saja, akan tetapi masih ada banyak faktor lain yang mempengaruhinya. Faktor lain yang dapat mempengaruhi loyalitas pemustaka dimaksud adalah adanya tingkat kepuasan dan kepercayaan pelanggan terhadap loyalitas pelanggan. Semakin tinggi tingkat kepuasan pelanggan dan kepercayaan pelanggan maka semakin tinggi tingkat loyalitas pemustaka. Andil terbesar yang mempengaruhi loyalitas pemustaka dari ketiga variabel dalam penelitian ini adalah faktor kualitas jasa layanan yang bersifat hard sebesar $82,83 \%$. Sementara konstribusi variabel jasa layanan soft sebesar $79,75 \%$ dan faktor akreditasi sebesar $80 \%$.

Kekuatan jasa layanan soft didukung oleh 8 komponen terdiri dari 4 komponen yang perlu dipertahkan keberadaannya oleh Direktorat Perpustakaan UII dan 4 komponen yang perlu ditingkatkan. Dari hasil uji t, 4 komponen yang perlu dipertahankan adalah meliputi: prosedur pelayanan dengan skor nilai $(113,837)$, kesesuaian jadwal layanan $(111,530)$, kesiapan pustakawan membantu mahasiswa kesulitan dalam proses peminjaman $(111,295)$, dan kerajinan pustakawan $(103,326)$. Sementara 4 komponen yang perlu ditingkatkan terdiri dari: kesiapan pustakawan membantu mahasiswa kesulitan dalam proses pencarian koleksi $(83,520)$, sikap simpatik pustakawan $(99,281)$, sikap sopan pustakawan $(97,992)$, dan keramahan pustakawan $(102,859)$.
Kekuatan jasa layanan hard didukung oleh 10 komponen terdiri dari 5 komponen yang perlu dipertahkan keberadaannya oleh Direktorat Perpustakaan UII dan 5 komponen yang perlu ditingkatkan. Dari hasil uji t, 5 komponen yang perlu dipertahankan adalah meliputi: kesesuaian penempatan fasilitas perpustakaan dengan skor nilai $(106,477)$, kebersihan lingkungan (103,290), kelengkapan fasilitas $(103,290)$, kualitas fasilitas $(102,172)$ dan jaminan keamanan $(103,333)$. Sementara 5 komponen yang perlu ditingkatkan terdiri dari: lokasi perpustakaan mudah dicapai kendaraan $(92,814)$, ketersediaan fasilitas dalam memenuhi kebutuhan pemustaka $(82,033)$, kenyamanan untuk berinteraksi $(94,195)$, keadilan dalan penerapan peraturan $(100,679)$, dan fasilitas perpustakaan dapat memenuhi kebutuhan secara cepat $(87,539)$.

Kekuatan jaminan mutu (akreditasi) didukung oleh 8 komponen terdiri dari 4 komponen yang perlu dipertahkan keberadaannya oleh Direktorat Perpustakaan UII dan 4 komponen yang perlu ditingkatkan. Dari hasil uji t, 4 komponen yang perlu dipertahankan adalah meliputi: perasaan puas pemustakan terhadap layanan yang diterima dengan skor nilai $(99,437)$, pemberian reward kepada mahasiswa yang paling rajin meminjam koleksi dan berkunjung ke perpustakaan $(95,476)$, pengorganisasian materi perpustakaan sudah baik $(94,163)$, dan perawatan koleksi dinilai sudah baik $(99,262)$. Sementara 4 komponen yang perlu ditingkatkan terdiri dari: ketersediaan koleksi dalam pemenuhan kebutuhan mahasiswa $(66,571)$, jumlah SDM (92,330), gedung/ruang, sarana dan prasarana dirasa belum memadai $(76,000)$, dan jadwal layanan 08.00-22.00 dirasa masih kurang $(102,859)$.

Lebih lanjut dengan merujuk pada hasil hitung Tabel 8 (Type Regression II) di bagan Coefficients terbukti bahwa angka signifikasi dari faktor yaitu $\mathrm{X}_{1}=0,000$ dan $\mathrm{X}_{2}=0,000>$ 0,05 ; dan $\mathrm{Y}=0,066$ lebih besar dari 0,05 . Hitungan tersebut membuktikan bahwa Type Regression II, yaitu variabel jasa layanan soft $\left(\mathrm{X}_{1}\right)$ dan jasa layanan hard $\left(\mathrm{X}_{2}\right)$ berpengaruh signifikan terhadap loyalitas pemustaka (Z). 
Sementara hitungan akreditasi perpustakaan (Y) tidak berpengaruh pada loyalitas pemustaka. Jumlah nilai $\mathrm{R}^{2}$ Tabel 7 senilai 0,344 , masalah itu membuktikan bahwa nilai kekuatan $\mathrm{X}_{1}, \mathrm{X}_{2}$ dan Y kepada Z senilai 34,4\% sementara sisa nilai angka $65,6 \%$ menunjukkan andil dari faktor-faktor lain yang tidak terdapat pada studi ini.

Kualitas layanan soft, hard, dan akreditasi (LSHA) dan loyalitas pelanggan memainkan peran penting dalam memastikan operasi yang berkelanjutan dan pengembangan layanan perpustakaan dalam jangka panjang. Studi ini mengetengahkan suatu paradigma penelitian terkini dalam upaya menyelidiki dengan jalan apa LSHA dapat terbangunnya loyalitas pelanggan dalam layanan perpustakaan dan dengan jalan apa dia bersinggungan terhadap mutu layanan, potret perpustakaan dan penjaminan mutu dalam membangun kesetiaan pemustaka. Studi empiris pada Direktorat Perpustakaan UII dilakukan untuk menguji model penelitian, dengan menggunakan analisis jalur. Studi ini menemukan bahwa LSHA memiliki pengaruh langsung terhadap loyalitas pelanggan tanpa melalui akreditasi (penjaminan mutu) sebagai mediator. Secara khusus, temuan baru penelitian ini menyoroti pentingnya peran mediasi yang dimainkan oleh citra perpustakaan dalam meningkatkan efek LSHA terhadap loyalitas pelanggan. Temuan penelitian ini memberikan wawasan yang bermanfaat mengenai bagaimana perpustakaan UII harus mengembangkan kebijakan LSHA yang akan meningkatkan citra perpustakaan dan penjaminan mutu, sehingga mengarah pada loyalitas pemustaka. Hasil studi ini disetujui oleh Yu-Hern Chang, dan Chung-Hsing Yeh (2017: 38-45) dalam studinya dengan hasil bahwa fungsi sosial perusahaan berdampak positif terhadap kesetiaan user, kepuasan pelanggan, mempunyai dampak positif terhadap potret perusahaan, mempunyai dampak positif terhadap mutu layanan. Sementara itu studi yang ada mengenai pengaruh mutu layanan terhadap loyalitas konsumen, kepuasan konsumen, dan potret perusahaan membuat peneliti terdahulu berhipotesis bahwa, mutu layanan berdampak positif kepada kesetiaan konsumen, mutu layanan berdampak positif bagi kepuasan konsumen, dan mutu layanan berdampak positif bagi potret perusahaan.

Hasil penelitian ini oleh responden dipersepsikan bahwa tingkat kualitas layanan di Direktorat Perpustakaan UII: layanan soft dalam kategori tinggi (79.75\%), layanan hard dalam kategori sangat tinggi $(82.83 \%)$, penjaminan mutu (akreditasi) dalam kategori tinggi (80\%), dan loyalitas pemustaka dalam klasifikasi sangat tinggi $(80,043 \%)$. Dari hasil studi ini dapat diinterpretasikan bahwa aspek terpenting kualitas layanan, penjaminan mutu dan loyalitas di perpustakaan untuk masa depan yang harus dipusatkan pada manajemen perpustakaan. Berdasarkan temuan penelitian ini, hal-hal yang perlu dilakukan di masa yang akan datang terkait dengan kualitas layanan adalah: (1) penyampaian layanan secara tepat waktu, (2) karyawan yang peduli, (3) akurasi penagihan, (4) komunikasi yang tepat tentang waktu penyampaian layanan, (5) ketepatan pelayanan, dan (6) kesediaan karyawan untuk membantu pasien. Sementara terkait dengan penjaminan mutu (akreditasi) perkara-perkara berikut ini perlu mendapatkan perhatian serius bagi Direktorat Perpustakaan UII antara lain: (1) pemberian layanan tepat waktu, (2) karyawan yang peduli, (3) akurasi penagihan atas keterlambatan pinjaman koleksi, (4) ketepatan waktu tentang pemberian layanan, (5) kecepatan pelayanan, dan (6) kesediaan karyawan untuk membantu pemustaka. Dengan kata lain, sikap karyawan terhadap pelanggan, komunikasi yang tepat dengan pelanggan, dan pemberian layanan yang akurat sangat penting bagi keberhasilan perpustakaan. Dapat dinyatakan bahwa, adanya inovasi layanan baru, sikap, komunikasi, ketepatan dan kecepatan layanan merupakan kunci untuk membuat pemustaka kembali ke perpustakaan yang sama.

Hasil studi ini didukung oleh peneliti terdahulu antara lain: 1) Meesala dan Paul (2018:261-269) berjudul Service quality, consumer satisfaction and loyalty in hospitals: Thinking for the future menerima hipotesis sepenuhnya karena adanya bukti bahwa peran 
mediasi kepuasan pasien berpengaruh terhadap loyalitas pelanggan. 2) Jung Cheol Shin (2017) dalam artikelnya berjudul Quality assurance systems as a higher education policy tool in Korea: International convergence and local contexts, memberikan penjelasan pentingnya layanan global pada sektor publik dalam penjaminan mutu di Korea. Di negara ini, modifikasi dalam konvergensi kebijakan merespons kekurangan dalam sistem penjaminan mutu yang ada daripada tekanan internasional untuk jaminan kualitas. Meskipun seiring waktu ada kemiripan yang tumbuh di tingkat global dalam penjaminan kualitas, 'prisma lokal' menyaring tekanan eksternal. Pendapat Jung ini dapat di implementasikan pada Direktorat Perpustakaan UII di masa mendatang perlunya layanan terpadu cecara modern dengan acara mengemas jenis layanan online dan offline, dimana perpustakaan dapat memberikan layanan internet untuk akses ejournal, e-book, e-repositori, dan lain-lain (yang ini sudah dilakukannya). Ke depan yang perlu dilakukan Direktorat Perpustakaan UII adalah adanya inovasi baru pelayanan koleksi digital secara online, dimana pemustaka dapat meminjam koleksi digital secara mandiri dengan bantuan seperangkat HP android yang dimiliki oleh pemustaka, selama ini yang dilakukan masih sistem konvensional yakni peminjaman koleksi tercetak secara offlline. 3) Wolter dkk. (2017: 458-476) dalam penelitian berjudul Creating Ultimate Customer Loyalty Through Loyalty Conviction and CustomerCompany Identification, dimana Wolter dkk ini juga berbasis pentingnya mempertahankan kepuasan pelanggan agar loyalitas pelanggan dapat diperoleh. Agar hal ini dapat diperoleh, perlu adanya strategi pemasaran dengan membuat identifikasi pelanggan yang bermanfaat untuk mendorong loyalitas pelanggan yang memungkinkan perpustakaan dapat meraih loyalitas pelanggan untuk mengatasi hambatan situasional, kompetitif, dan finansial agar pelanggan dapat memanfaatkan jasa perpustakaan dengan optimal.
Temuan lain yang mendukung penelitian ini adalah studi yang dilakukan oleh Kasiri dkk. (2017:91-97), hasil studinya memberikan hasil bahwa: (1) penyatuan standarisasi dan penyelarasan layanan sevis amat urgen untuk meninggikan mutu peladenan; (2) pembakuan mutu mempunyai pengaruh lebih unggul bagi mutu peladenan jika disetarakan dengan penyesuaian; (3) mutu fungsional berdampak lebih unggul terhadap kepuasan konsumen jika dibandingkan dengan mutu teknis; dan (4) kepuasan nasabah memiliki kualitas yang substansial terhadap kesetiaan konsumen. Sokongan studi ini merupakan perluasan lingkungan kerja terintegrasi untuk mengkaji fungsi standardisasi dan kustomisasi terhadap mutu layanan. Sementara itu Lierop dan Geneidy (2016:50-59) mengetengahkan variabel kepuasan dari aspek kebersihan, aspek aman, dan aspek kualitas layanan. Ketiga variabel ini ada pengaruhnya terhadap loyalitas pelanggan. Lebih lanjut oleh Dahan dkk (2016:38-43) juga mendukung hasil studi ini yang menyatakan bahwa hasil penelitian yang dilakukan melaporkan nilai positif untuk kedua analisis gap di semua dimensi kualitas layanan. Berdasarkan masukan dari 382 responden, hasilnya menunjukkan bahwa tingkat kualitas layanan yang dirasakan melebihi tingkat yang diharapkan dari yang diinginkan. Secara khusus, pengguna puas dengan layanan yang diberikan. Hasil penelitian ini merupakan panduan untuk pengambilan keputusan yang efektif oleh perpustakaan dalam administrasi dan alokasi sumber daya untuk memastikan pencapaian visi dan misi perpustakaan. Hal yang sama diungkapkan oleh Taplin (2013:238246), bahwa adanya tingkat kepuasan yang tinggi yang melebihi harapan akan berdampak terhadap kesetiaan (loyalitas) konsumen. Perspektif lain disampaikan oleh Ahmad (2014:571-580), bahwa ada komponen yang perlu mendapatkan perhatian oleh perpustakaan digital pada saat melakukan layanan adalah penekanan pada aspek kualitas lingkungan, kualitas pengiriman, kualitas hasil, standar, dan prosedur, sehingga kesemuanya ini akan berdampak pada kepuasan pengguna. 


\section{E. KESIMPULAN}

Atas dasar kajian tersebut, dapat disimpulkan bahwa: Kualitas layanan di Direktorat Perpustakaan UII dalam kondisi tinggi s.d sangat tinggi, sementara tingkat kualitan penjaminan mutu (akreditasi) berkategori tinggi, dan loyalitas pemustaka pada tataran sangat tinggi. Hasil analisis data menunjukkan bahwa variabel kualitas soft dan hard services ada pengaruh secara langsung terhadap loyalitas pemustaka. Sementara itu variabel soft dan hard services melalui variabel akreditasi berpengaruh terhadap loyalitas pemustaka.

Dari uraian tersebut, maka dapat diberikan saran-saran sebagai berikut:

a. Direktorat Perpustakaan UII sudah saatnya meningkatan mutu jasa layanannya dengan membuat inovasi baru berupa layanan koleksi digital secara online dengan bantuan seperangkat HP android yang dimiliki oleh pemustaka.

b. Direktorat Perpustakaan UII sudah seharusnya menindaklanjuti dari hasil studi ini, terkait dengan kekuatan komponen layanan soft, hard, dan jaminan mutu (akreditasi) apa yang perlu dipertahankan dan apa yang harus ditingkatkan.

c. Untuk peneliti selanjutnya, disarankan untuk meneliti dengan tema yang sama dengan melibatkan mutu jasa layanan di seluruh perpustakaan di lingkunan UII (tidak terbatas) pada Direktorat Perpustakaan UII saja.

\section{DAFTAR PUSTAKA}

Ahmad, M. \& Abawajy, J.H. (2014). Digital library service quality assessment model. Procedia - Social and Behavioral Sciences, $129,571-580$.

Blackmur, D., (2004). Issues in higher education quality assurance. Australian Journal of Public Administration, 63 (2), 105-116.

Brennan, J., Shah, T., (2000). Managing quality in higher education: an international perspective on institutional assessment and change. OCED, SRHE and Open University Press, UK.

Dahan, S. M. et al. (2016). Surveying users' perception of academic library services quality: a case study in Universiti Malaysia Pahang (UMP) Library. The Journal of Academic Librarianship, 42, 38-43.

Dewi, M. U. P. (2017). Peran kualitas layanan dan merchandising terhadap kepuasan dan loyalitas pelanggan. Laporan Penelitian. Yogyakarta: Fakultas Eknomi UII.

Driver, C. \& Johnston, R. (2001). Understanding service customers the value of hard and soft attributes, Journal of Service Research, 4(2): 130-139.

HIMMAH UII Online. (2016). Penuhi rasio, UII kurangi jumlah mahasiswa baru http://lpmhimmahuii.org/2016/08/penuhirasio-uii-kurangi-jumlah-mahasiswa-baru2/

Jung Cheol Shin (2017). Quality assurance systems as a higher education policy tool in Korea: International convergence and local contexts. International Journal of Educational Development October 2017.

Kasiri, L.A. et al. (2017). Integration of standardization and customization: Impact on service quality, customer satisfaction, and loyalty. Journal of Retailing and Consumer Services, 35, 91-97.

Lierop, Dea van dan Ahmed El-Geneidy. (2016) Enjoying loyalty: The relationship between service quality, customer satisfaction, and behavioral intentions in public transit. Research in Transportation Economics, 59, 50-59. 
Meesala, Appalayya \& Paul, Justin. (2018). Service quality, consumer satisfaction and loyalty in hospitals: Thinking for the future. Journal of Retailing and Consumer Services, 40, 261-269.

Orsingher, C., (2006). Assessing quality in european higher education institutions: dimension, methods, and procedures. Physica-Verlag, Heidelberg.

Pedramnia, Modiramani and Ghanbarabadi (2012). An analysis of service quality in academic libraries using LibQUAL scale. Library Management, 33(3), 159-167 Emerald [Online]. Available at: http://www.emeraldinsight.com/01435124.htm

Perellon, J.F., (2005). Path dependency and the politics of quality assurance in higher education. Journal of Tertiary Educational and Management, 11, 279-298.

Perellon, J.F., (2007). Analysing quality assurance in higher education: proposals for a conceptual framework aand methodological implications. In: Westerheijden, D.F., Stensaker, B., Rora, M.J. (Eds.), Quality Assurance in Higher Education. Springer, Dordrecht, the Netherlands, pp. 155-178.
Riduwan. (2015). Pengantar statistika untuk penelitian pendidikan, sosial, ekonomi, komunikasi, dan bisnis cet. ke 8. Bandung: Alfabeta.

Salter, B., \& Tapper, T. (2000). The politics of governance in higher education: The Case of Quality Assurance. Journal of Political Studies, 48, 66-87.

Sugiyono. (2011). Metode penelitian kuantitatif, kualitatif dan $R \& D$. Bandung: Alfabeta.

Taplin, Ross H. (2013). The influence of competition on visitor satisfaction and loyalty. Journal of Tourism Management, $36,238-246$.

Wolter, J. S. et al. (2017). Creating ultimate customer loyalty through loyalty conviction and customer-company identification. Journal of Retailing, 93 (4), 458-476.

Yu-Hern Chang \& Chung-Hsing Yeh. (2017). Corporate social responsibility and customer loyalty in intercity bus servis. Transport Policy, 59, 38-45. 


\section{DAFTAR GAMBAR}

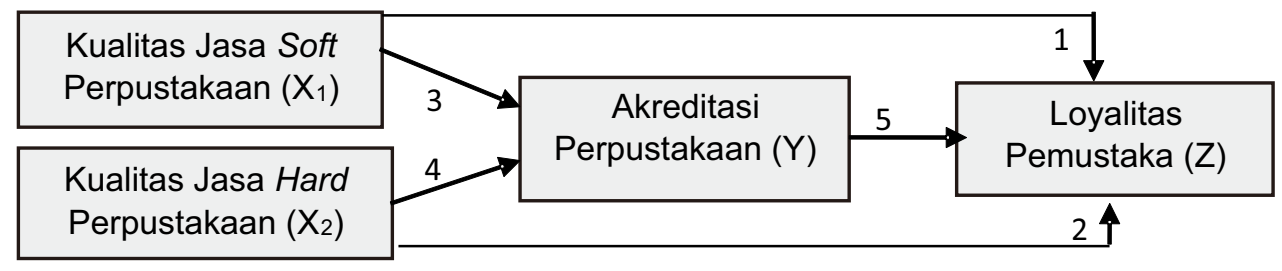

Gambar 1. Paradigma Penelitian

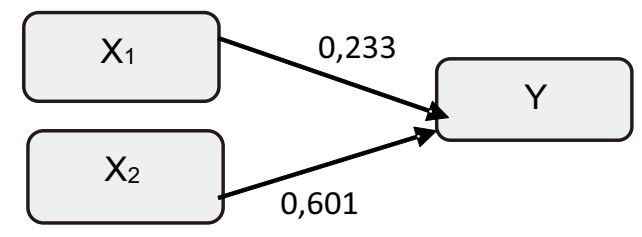

Gambar 2. Analisis Regresi Tipe I

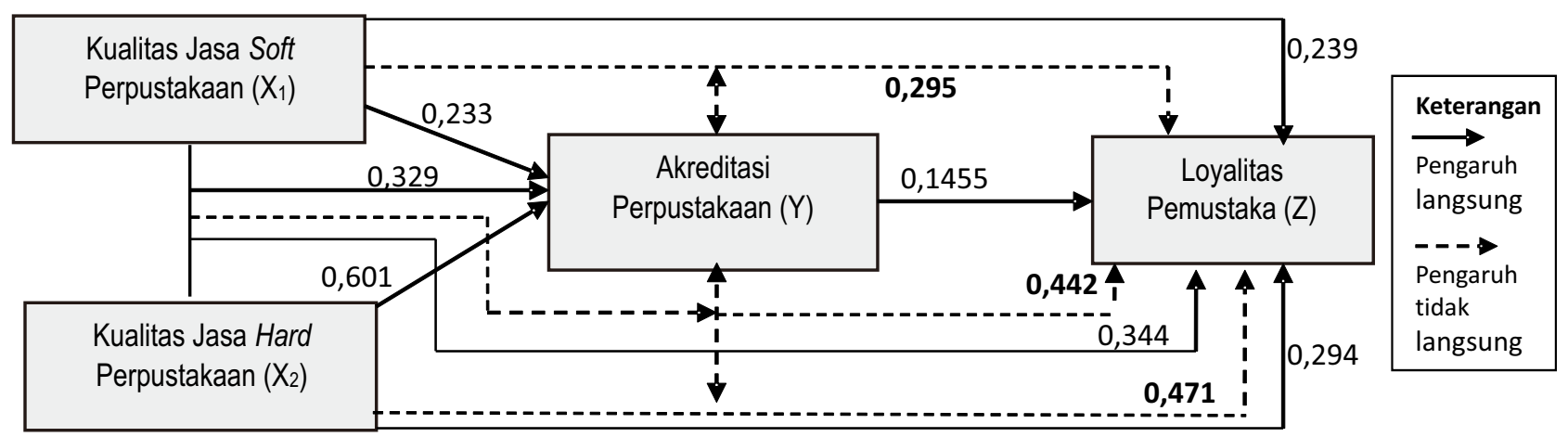

Gambar 3. Analisis Regresi Tipe II 


\section{DAFTAR TABEL}

Tabel 1. Tahun Angkatan Mahasiswa UII

\begin{tabular}{lcrr}
\hline No & $\begin{array}{c}\text { Tahun } \\
\text { Angkatan }\end{array}$ & Jumlah & $\begin{array}{c}\text { Persentase } \\
\text { (\%) }\end{array}$ \\
\hline 1 & 2017 & 139 & $55.16 \%$ \\
2 & 2016 & 25 & $9.92 \%$ \\
3 & 2015 & 23 & $9.13 \%$ \\
4 & 2014 & 27 & $10.71 \%$ \\
5 & 2013 & 34 & $13.49 \%$ \\
\hline
\end{tabular}

Tabel 2. Fakultas Asal Responden Berasal

\begin{tabular}{llrr}
\hline No & Fakultas & Jumlah & $\begin{array}{c}\text { Persentase } \\
\text { (\%) }\end{array}$ \\
\hline 1 & FE & 8 & $3.17 \%$ \\
2 & FIAI & 86 & $34.13 \%$ \\
3 & FK & 1 & $0.40 \%$ \\
4 & FMIPA & 34 & $13.49 \%$ \\
5 & FPSB & 77 & $30.56 \%$ \\
\hline
\end{tabular}

Tabel 3. Hasil Uji Reliabilitas dan Validitas

\begin{tabular}{|c|c|c|c|c|c|c|c|c|}
\hline \multirow{2}{*}{ Uraian } & \multirow{2}{*}{$\begin{array}{c}\text { Instrumen } \\
\text { Jasa Soft } \\
\mathrm{r}_{\text {hitung }}\end{array}$} & \multirow{2}{*}{$\begin{array}{c}\text { Instrumen } \\
\text { Jasa Hard } \\
\mathrm{r}_{\text {tabel }}\end{array}$} & \multirow{2}{*}{$\begin{array}{c}\begin{array}{c}\text { Instrumen } \\
\text { Jaminan } \\
\text { Mutu } \\
\text { (Akreditasi ) }\end{array} \\
\mathrm{r}_{\text {hitung }}\end{array}$} & \multicolumn{5}{|c|}{ Instrumen Loyalitas Pemustaka } \\
\hline & & & & $r_{\text {tabel }}$ & $\mathrm{r}_{\text {hitung }}$ & $r_{\text {tabel }}$ & $\mathbf{r}_{\text {hitung }}$ & $\mathrm{r}_{\text {tabel }}$ \\
\hline Reliabilitas & 0.904 & 0.6 & 0.895 & 0.6 & 0.750 & 0.6 & 0.798 & 0.6 \\
\hline Validitas & $\begin{array}{r}0.590- \\
0.741\end{array}$ & $\begin{array}{r}0.138- \\
0.181\end{array}$ & $\begin{array}{r}0.489- \\
0.718\end{array}$ & $\begin{array}{r}0.138- \\
0.181\end{array}$ & $\begin{array}{r}0.316- \\
0.535\end{array}$ & $\begin{array}{c}0.138- \\
0.181\end{array}$ & $\begin{array}{r}0.459- \\
0.614\end{array}$ & $\begin{array}{r}0.138 \\
0.181\end{array}$ \\
\hline
\end{tabular}

Tabel 4. Kategori Tingkatan Tinggi/ Rendahnya Kualitas Layanan

\begin{tabular}{lr}
\hline Nilai / Skor & \multicolumn{1}{c}{ Kategori } \\
\hline $\mathbf{0 - 2 0}$ & Sangat Rendah \\
$\mathbf{2 0 . 0 1}-\mathbf{4 0}$ & Rendah \\
$\mathbf{4 0 . 0 1}-\mathbf{6 0}$ & Sedang \\
$\mathbf{6 0 . 0 1}-\mathbf{8 0}$ & Tinggi \\
$\mathbf{8 0 . 0 1}-\mathbf{1 0 0}$ & Sangat Tinggi \\
\hline
\end{tabular}


Tabel 5. Nilai Prediktor: (Konstan) Jalur Model I Summary Variabel $\mathrm{X}_{1}$ dan $\mathrm{X}_{2}$

\begin{tabular}{ccccc}
\hline Model & $\mathbf{R}$ & R Square & $\begin{array}{c}\text { Adjusted } \\
\text { Square }\end{array}$ & $\begin{array}{c}\text { Std. Error of } \\
\text { the Esimate }\end{array}$ \\
\hline $\mathbf{1}$ & $.755^{\mathrm{a}}$ & .570 & .566 & 1.862293 \\
\hline Predictors: (Constant), Jasa Hard $\left(X_{2}\right)$, Jasa Soft $\left(X_{1}\right)$ & &
\end{tabular}

Predictors: (Constant), Jasa Hard $\left(X_{2}\right)$, Jasa Soft $\left(X_{\nu}\right)$

Tabel 6. Nilai Koefisien Jalur Model I Pengaruh Variabel $\mathrm{X}_{1}$ dan $\mathrm{X}_{2}$ terhadap $\mathrm{Y}$

\begin{tabular}{|c|c|c|c|c|c|c|}
\hline & \multirow[t]{2}{*}{ Model } & \multicolumn{2}{|c|}{$\begin{array}{l}\text { Unstandardized } \\
\text { Coefficients }\end{array}$} & \multirow{2}{*}{$\begin{array}{c}\text { Standardized } \\
\text { Coefficients } \\
\text { Beta }\end{array}$} & \multirow[t]{2}{*}{$\mathbf{t}$} & \multirow[t]{2}{*}{ Sig. } \\
\hline & & B & Std. Error & & & \\
\hline \multirow[t]{3}{*}{1} & (Constant) & 5.575 & 1.134 & & 4.918 & .000 \\
\hline & Jasa Soft $\left(\mathrm{X}_{1}\right)$ & .215 & .046 & .233 & 4.658 & .000 \\
\hline & Jasa Hard $\left(\mathrm{X}_{2}\right)$ & .439 & .036 & .601 & 12.037 & .000 \\
\hline
\end{tabular}

Dependent Variable: Akreditasi (Y)

Tabel 7. Nilai Prediktor: (Konstan) Jalur Model II Summary Variabel $X_{1}$ dan $X_{2}$

\begin{tabular}{ccccc}
\hline Model & $\mathbf{R}$ & R Square & $\begin{array}{c}\text { Adjusted } \\
\text { Square }\end{array}$ & $\begin{array}{c}\text { Std. Error of the } \\
\text { Esimate }\end{array}$ \\
\hline $\mathbf{1}$ & $.586^{\mathrm{a}}$ & $\mathbf{3 4 4}$ & .336 & 1.97738 \\
\hline Predictors: Predictors: (Constant), Akreditasi $(Y)$, Jasa Soft $\left(X_{1}\right)$, Jasa Hard $\left(X_{2}\right)$ &
\end{tabular}

Tabel 8. Nilai Koefisien Jalur Model II Pengaruh Variabel $X_{1}$ dan $X_{2}$ terhadap Y

\begin{tabular}{|c|c|c|c|c|c|c|}
\hline & \multirow[t]{2}{*}{ Model } & \multirow{2}{*}{$\begin{array}{c}\text { Unstandardized } \\
\text { Coefficients } \\
\text { B }\end{array}$} & \multirow{2}{*}{$\begin{array}{c}\text { Standardized } \\
\text { Coefficients } \\
\text { Std. Error }\end{array}$} & \multirow{2}{*}{$\begin{array}{c}\mathbf{t} \\
\text { Beta }\end{array}$} & \multicolumn{2}{|c|}{ Sig. } \\
\hline & & & & & & \\
\hline 1 & (Constant) & 5.083 & 1.260 & & 4.033 & .000 \\
\hline & Jasa Soft $\left(X_{1}\right)$ & .190 & .051 & .239 & 3.709 & .000 \\
\hline & Jasa Hard $\left(\mathrm{X}_{2}\right)$ & .184 & .049 & .294 & 3.786 & .000 \\
\hline & Akreditasi (Y) & .124 & .067 & .145 & 1.850 & .066 \\
\hline
\end{tabular}

Dependent Variable: Loyalitas Pemustaka (Z) 